\title{
As antenas do caracol, de Dirce Waltrick do Amarante
}

\author{
São Paulo: Iluminuras, 2012. \\ Mônica de Ávila Todaro \\ Doutora em Educação - UNICAMP; \\ Docente e pesquisadora - UNINOVE. \\ São Paulo, SP - Brasil. \\ mavilatodaro@uninove.br
}

"P’ra mim o longe é mais perto
Do que o presente lugar. [...]

Viagem circulatória

Num expresso de vagões-leitos"

(SÁ-CARNEIRO, 2005)

As antenas do caracol, obra de Dirce Waltrick do Amarante, tradutora, ensaísta e docente da Universidade Federal de Santa Catarina, finalista do prêmio Jabuti em 2010, coloca a Iluminuras novamente entre as mais sérias e comprometidas editoras de São Paulo, num cenário repleto de outras tantas que buscam seu espaço no mercado editorial da mais populosa cidade brasileira. Tal como Mario de Sá-Carneiro, de quem lembrei ao ler o livro que agora resenho, Amarante procura inovar e manifestar-se sem disfarces, o que não é muito comum em ensaios acadêmicos.

A obra em questão é dividida pela autora em duas partes. A primeira, "Casos concretos", e a segunda, "Notas teóricas", perfazendo, ao todo, 14 ensaios. Na primeira parte a autora analisa livros e seus enredos e na segunda escreve a respeito dos conceitos de criança e infância, sobre o gosto pela arte e, por último, relaciona arte, ética e educação. Em ambas, Amarante (des e re) constrói conceitos e concepções, por meio de reflexões críticas, sem medo de expor o que pensa.

O título, As antenas do caracol, é, segundo a autora, "[. . .] uma homenagem ao ensaio 'Sobre a gênese da burrice', no qual, a respeito da educação, Adorno e Horkheimer associam o caracol à formação da sensibilidade e ao desenvolvimento da inteligência humana" (p. 11). Os filósofos citados comparam a inteligência a uma antena de caracol que, diante de um obstáculo, recolhe-se ao abrigo protetor do corpo. 
$\mathrm{Na}$ verdade, os leitores que quiserem embarcar nas curtas viagens circulatórias (cada ensaio tem entre 4 e 14 páginas) serão brindados com palavraspassaporte emprestadas de autores brasileiros como Paulo Freire, Ana Mae Barbosa, Tatiana Belinky, Câmara Cascudo, Alfredo Bosi, Marisa Lajolo, Regina Zilberman e Myriam Ávila, entre outros, que dialogam com escritores estrangeiros como Bauman, Adorno, Barthes, Baudelaire, Benjamin, Bettelheim, Bourdieu, Heidegger etc. São pensamentos recortados e colados por Amarante de modo lúdico, como num jogo infantil que dá prazer a quem brinca de escrever e para aqueles que querem jogar. $\mathrm{Na}$ minha resenha-tabuleiro percorrerei o caminho não justo, mas possível, indicado por dados de uma jogadora-pedagoga que na prática educativa convive, diariamente, com a tarefa de selecionar, intencionalmente, conteúdos conceituais, atitudinais e procedimentais.

Para os preconceituosos de plantão, no primeiro ensaio da parte I, "Quase a mesma coisa: irmãos Grimm em quadrinhos", a autora desmistifica a crença de que devemos desconfiar de todo e qualquer tipo de adaptação literária. Amarante elogia a versão dos quadrinistas brasileiros e afirma que "[. . .] grande parte dos quadrinhos conserva não apenas a atmosfera original dos contos, como também os enredos das histórias [...]" (p.18).

No terceiro ensaio, ainda da primeira parte, Amarante esclarece e critica o fato de o consagrado Monteiro Lobato ter sofrido censura sem o direito de defesa ("a um morto nada se recusa", como ensina Sá-Carneiro). Para ela, o fato de tentar excluir o livro Caçadas de Pedrinho da lista do Programa Nacional Biblioteca da Escola, do MEC, resultou de uma "[...] leitura míope ou ligeira que, sobretudo hoje, se faz de sua obra [...] " (p.28) e, no seu entendimento, para modificar este quadro "é preciso estudar o contexto histórico da obra de Monteiro e as expressões da época, sem ignorar as tomadas de posição do autor [...]" (p.30).

Amarante denomina a segunda parte do livro de "Notas teóricas" e as divide em três, a saber: "Sobre os conceitos de criança e infância", "Sobre arte, um gosto artificialmente adquirido" e "Sobre arte, ética e educação".

Na primeira nota teórica são apresentadas algumas reflexões sobre a infância no mundo contemporâneo, indo de uma visão mais filosófica para outra mais sociológica e apocalíptica. A nota parte da comparação das crianças a caracóis com antenas tateantes que precisam de incentivo e estímulo para ganhar confiança e finaliza com as ideias de Paulo Freire, para quem não haveria educação se o homem fosse um ser acabado. 
Ao tratar a respeito de arte, ética e educação, nas duas outras notas, a autora traz posições e análises que a revelam "freiriana" ao defender os princípios da incerteza e da incompletude presentes em obras do autor como Educação $e$ mudança, Pedagogia do oprimido e Pedagogia da autonomia.

Um livro como As antenas do Caracol convida os leitores a praticar um diálogo crítico com Dirce Waltrick do Amarante e, nesse espaço democrático entre a escritora e aquele que a frui, reside o significado e a importância da obra-viagem circulatória na qual o longe dos autores por ela recortados e colados se torna o presente lugar.

\section{Referências}

SÁ-CARNEIRO, Mario de. Poesia. Organização de Cleonice Berardinelli. Rio de Janeiro: Agir, 2005. (Os Nossos Clássicos). 